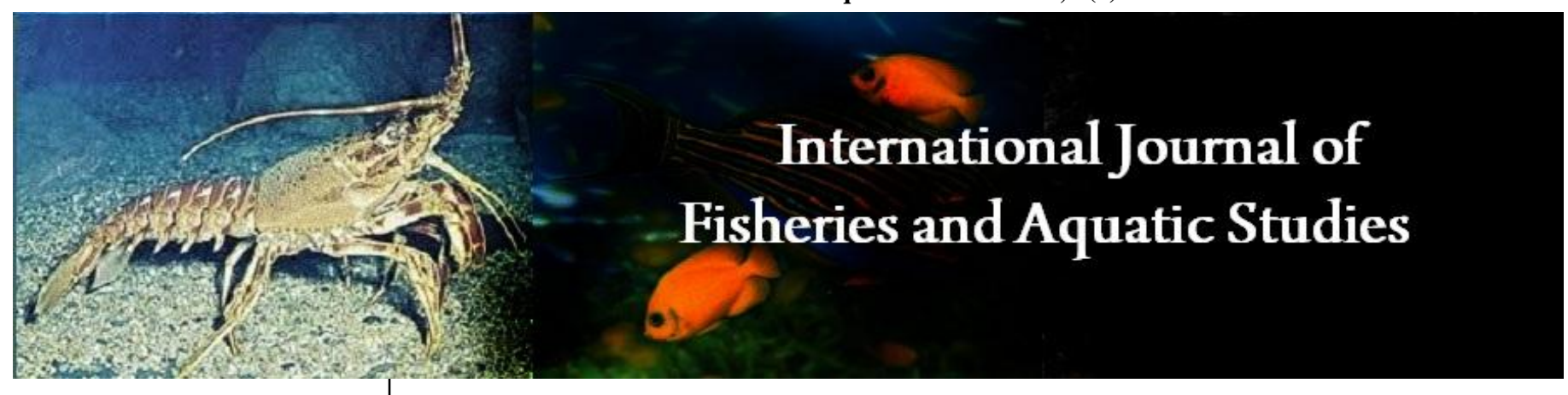

E-ISSN: 2347-5129

P-ISSN: 2394-0506

(ICV-Poland) Impact Value: 5.62

(GIF) Impact Factor: 0.549

IJFAS 2020; 8(5): 96-106

(C) 2020 IJFAS

www.fisheriesjournal.com

Received: 07-07-2020

Accepted: 09-08-2020

Sahadevan P

Post Graduate Department of Aquaculture and Fisheries

Microbiology, MES Ponnani

College, Ponnani, Malappuram,

Kerala, India

Sureshkumar $\mathbf{S}$

School of Ocean Science and

Technology, Kerala University of Fisheries and Ocean Studies,

Panangad, Kochi, Kerala, India

Corresponding Author:

Sahadevan P

Post Graduate Department of

Aquaculture and Fisheries

Microbiology, MES Ponnani

College, Ponnani, Malappuram,

Kerala, India

\section{A study to understand the reasons for the low productivity of shrimp farms in Kerala}

\author{
Sahadevan P and Sureshkumar S
}

DOI: $\underline{\text { https://doi.org/10.22271/fish.2020.v8.i5b.2310 }}$

\begin{abstract}
Kerala is an important state contributing to farmed shrimp production in India. However, the productivity of shrimp farms in the state is the lowest among all Indian states. The present study was undertaken to understand the reasons for the low productivity of shrimp farms in the state of Kerala. For the collection of data, a survey was conducted among 220 shrimp farms with a total water spread area of 1,113.77 ha (traditional farms: 162 farms with 845.32 ha. area and scientific farms: 58 farms with 268.45 ha. area). Data were collected for two consecutive crops during the period from November 2016 to May, 2018. Analysis of information collected in the present study revealed that over-reliance on traditional mode of farming, lack of species diversity, improper site selection, insufficient attention paid on construction of ponds, inadequate pond preparation, poor pond management, use of poor quality of seed, nonacclimatisation of seed, use of sub optimal stocking density, poor dissolved oxygen management, insufficient water exchange, inadequate feeding, inadequate management of plankton growth, recurrence of diseases, poaching, shortage of labourers, discontinuance of paddy farming, failure in year- round utilisation of ponds etc. were found to be the principal reasons for the reported low productivity of shrimp farms in Kerala.
\end{abstract}

Keywords: Aquaculture, productivity, shrimp production, traditional farming

\section{Introduction}

Aquaculture of shrimps and prawns has made significant advances during the last four decades in many parts of the world, including India ${ }^{[1]}$. In the year 2018, the world produced around 4 million metric tonnes $(\mathrm{t})$ of farmed shrimp which represents around $54 \%$ of the total global shrimp production ${ }^{[2]}$. During 2017-2018, India produced 6.80 lakh t of shrimp through farming ${ }^{[3]}$. Kerala is one of the important states contributing to farmed shrimp production in India. The state has 65,214 ha. of water area amenable for brackish water aquaculture ${ }^{[4]}$. In addition, it has 12,873 hectare of prawn filtration fields which are utilised for rice cum shrimp farming ${ }^{4}$. The state also has a very long history of farming shrimp. In spite of having very rich and varied water resources and long tradition in farming ${ }^{[5]}$, shrimp aquaculture yet to take off in a big way in Kerala. The productivity (viz., the average weight of shrimp harvested per unit area per year) of shrimp farms in Kerala is also the lowest among all Indian states. As per the latest report ${ }^{[6]}$ published by the Marine Products Export Development Authority (MPEDA), the productivity of shrimp farms in India is $4.45 \mathrm{t} \mathrm{ha}^{-1}$ year-1 $^{-1}$ whereas that of Kerala is only $0.54 \mathrm{t}$ $\mathrm{ha}^{-1}$ year $^{-1}$. According to the report, the productivity of shrimp farms in other states of the country is as follows- Gujarat: 7.28, Andhra Pradesh: 7.15, Tamil Nadu: 4.90, Maharashtra: 4.70, Odisha: 3.57, Karnataka: 2.20, West Bengal: 1.30 and Goa: $2.40 \mathrm{t} \mathrm{ha}^{-1}$ year $^{[1]}$.

Profitability of shrimp farming operation depends, to a very great extent, on factors like proper selection of site, design and construction of ponds, intensity of farm management, production and productivity. The productivity, on the other hand is a direct function of the level of technology adopted and the species farmed. Evaluation of the published information in the field reveals in unambiguous terms that there is perceptible improvement in the productivity of shrimp farms in the country and in most of the states over the last four decades. But in Kerala the productivity figure remains more or less static during the period, indicating the need for identifying the reasons for it and rectifying the shortcomings, if any.

A fairly large number of studies exist on various aspects of prawn farming in the state of Kerala. However very few studies ${ }^{[7]}$ investigated the reasons for the low productivity of shrimp farms in 
the state. In the context, the present study is undertaken. In addition to academic interest the results of the present study are expected to provide valuable practical information which would throw light on the ways to improve the shrimp production of the state. It also reveals areas which deserve immediate attention of the planners and administrators for the sustainable development of the sector.

The term shrimps and prawns are used synonymously in the present paper due to the absence of systematic basis to mark a distinction, as opined by Wickins ${ }^{8}$ and Holthuis ${ }^{[9]}$.

\section{Materials and Methods}

The present study was part of a larger study which was meant for investigating various aspects like the status, problems and economics of shrimp farming in the state of Kerala. The study was conducted in the shrimp farming belt of the state viz., coastal areas of Thiruvananthapuram, Kollam, Alapuzha, Ernakulam, Thrissur, Malappuram, Kozhikkode, Kannur and Kasargod districts and the low-lying areas which lie adjacent to the backwaters in Kottayam district (fig. 1).

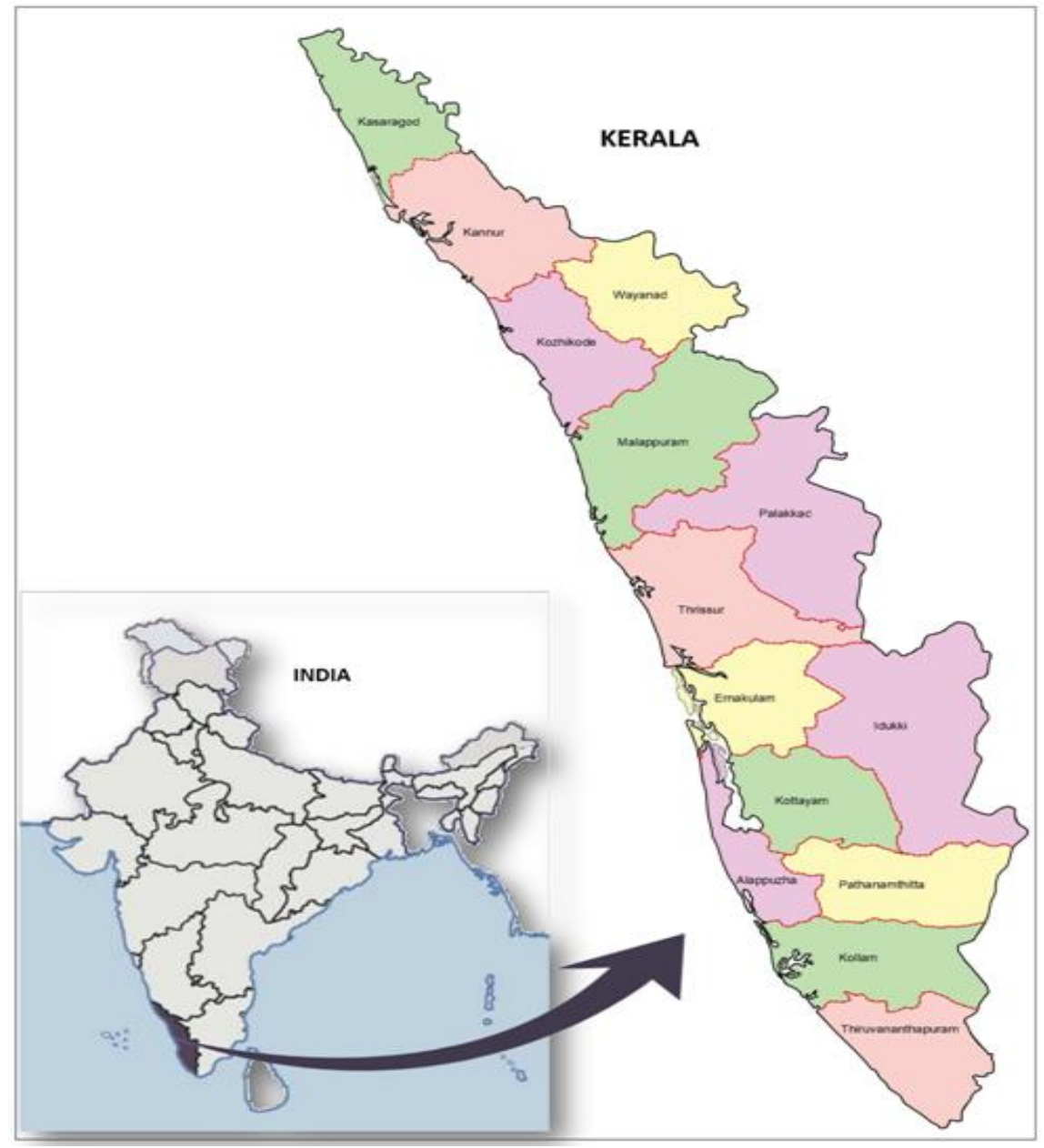

Fig 1: Study area

Experience coupled with the information collected in a presurvey enquiry revealed that in Kerala, two types of shrimp farming are in practice. They are traditional prawn farming and scientific prawn farming. Traditional farming relies on natural stocking of seeds (seeds brought in during the high tides) and supplementary stocking, if done any. Farming begins when the salinity builds up after the South-West monsoon (October- December), and ends with the final harvesting of prawn which is done just before the monsoon (April- May). In scientific tiger shrimp (Penaeus monodon (Fabricius, 1798) farming, crops are taken in different farms either as summer crop (January/ March - April/ June) or as monsoon crop (April/ May- July/ August). In farming of Pacific white shrimp (Litopenaeus vannamei (Boone, 1931), the trend is for year- round culture with no distinct crop season.

The source of data for the present study was a survey carried out among the shrimp farms functioning in the above districts. For the collection of data simple random sampling method was employed. For the purpose, lists of all shrimp farms in the districts were collected from the respective offices of the Fish Farmers' Development Agencies and from the office of the Marine Products Export Development Authority. A consolidated list, each of traditional farms and scientific farms, was prepared avoiding duplications. These lists formed the basis for the present study. A sample of farms was selected from each list by employing simple random sampling technique and data on topics of interest were collected from them using an appropriate questionnaire designed for the purpose and which was pre-tested. The questionnaire was in vernacular language $i$.e., Malayalam.

For the study a total of 220 shrimp farms with a total water spread area of $1,113.77$ ha were selected (traditional farms: 162 farms with 845.32 ha. area and scientific farms: 58 farms with 268.45 ha. area). Data were collected for two consecutive crops during the period from November 2016 to May 2018. Complete data were collected on various aspects of interest in the present study by frequent visits and from the 
farm records maintained. The various information collected which were expected to have a bearing on shrimp production and productivity were compared with relevant farming standards/ scientific recommendations to arrive at meaningful conclusions.

\section{Results and Discussion}

3.1. Over reliance on traditional mode of farming

One of the most important reasons for the low productivity of shrimp farms in Kerala is the fact that the majority of the farms undertake traditional mode of farming and they are low-input systems. These farm units do subsistence farming and are tide-fed, wherein production and profitability are low. The percent distribution of traditional and scientific shrimp farming units in Kerala in terms of number and extent (registered area and actual water spread area) is provided in figure 2 .

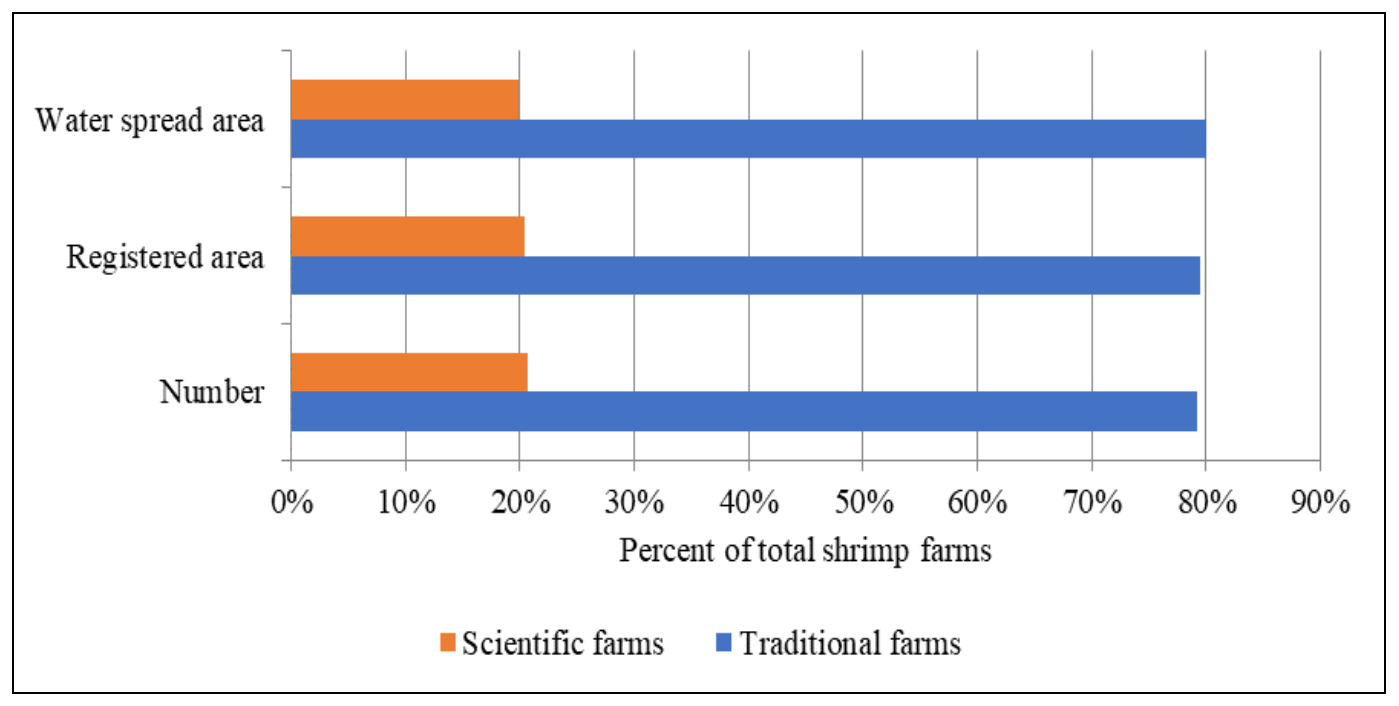

Fig 2: Percent distribution of traditional and scientific shrimp farming units.

Unnithan ${ }^{10}$ discussed the demerits of traditional system of prawn farming in detail. According to him in traditional system, the harvest would be a mix of commercially important and less important species of prawns. In these systems, since no sufficient time is allowed for the growth of the prawns trapped inside, the catch would contain undersized prawns to a considerable extent. Predatory organisms entering the field along with the tidal water would eat away a good number of the prawns. Further, since the stocking is fully dependant on nature, no control over the stocking density with regard to the extent, and productivity of the field is possible and the fields may sometimes be over-stocked or understocked. Because of competition for food and space, overstocking leads to poor growth of prawns. Understocking, on the other hand, results in under exploitation of the field. Both leads to lowering of the productivity of farms.

\subsection{Lack of species diversity}

Brackish water shrimp culture in Kerala is more or less restricted to a single species i.e., the tiger prawn (P. monodon) and to a very limited extent to the Indian white prawn $(P$. indicus) and the Pacific white shrimp (L. vannamei). In the study, it has been found that $95.17 \%$ of the traditional farms which undertook supplementary stocking used hatchery produced seeds of tiger prawn. Others stocked the seeds of white prawns (Indian white prawn and Pacific white shrimp). The rationale behind supplementary stocking of tiny hatchery produced seeds of shrimps in a system in which there is no control over the entry of predatory and weed fishes is questionable.

In the scientific farming sector, $91.38 \%$ of the farms cultured $P$. monodon, $5.17 \%$ cultured $P$. indicus and $3.45 \%$ cultured $L$. vannamei. In terms of area the corresponding figures were $90.42 \%, 1.15 \%$ and $8.43 \%$, respectively.

As per the statistics published by the Marine Products Export
Development Authority ${ }^{[6]}$, L. vannamei is farmed in $61.27 \%$ of the total area under shrimp farming in India. Further, except in Kerala and to some extent in West Bengal (7.47\%), in all other states L. vannamei occupies most of the areas under shrimp farming. L. vannamei was farmed in $97.07 \%$ of the total area under shrimp farming in Andhra Pradesh, 99.28 $\%$ in Gujarat, $99.89 \%$ in Tamil Nadu, $100 \%$ in Maharashtra, $97.07 \%$ in Odisha, $100 \%$ in Goa and $56.92 \%$ in Karnataka, in the year 2017-18 ${ }^{[3]}$. Kerala is the only state in India which relies almost entirely on $P$. monodon.

The failure of the state of Kerala to shift from $P$. monodon to $L$. vannamei is one of the principal reasons for the low productivity of the shrimp farms. L. vannamei is generally farmed at high density resulting in higher productivity. Sahadevan ${ }^{[7,11]}$ attributed reluctance of farmers to shift from tiger prawn to pacific white shrimp to the observed low productivity of shrimp farms in Kerala. Modern prawn farming is a dynamic process in which optimum per unit area production depends on highly manipulatable population density adjustable with quantum of feed and the conversion ratio of the species concerned.

\subsection{Improper site selection}

All shrimp farms studied were found to be situated in lowlying brackish water areas. Traditional farms are tide-fed and are mostly not fully drainable except perhaps during the periods of the lowest low tide. A sizeable number of scientific shrimp farms were also not fully drainable (figure 3 ). These farms cannot be drained completely and dried, as and when required. This inhibits mineralization of organic matter in the pond bottom which results in lowering of the primary productivity and existence of unhealthy bottom conditions. As a result, maximum growth of shrimp cannot be obtained in many farms. 


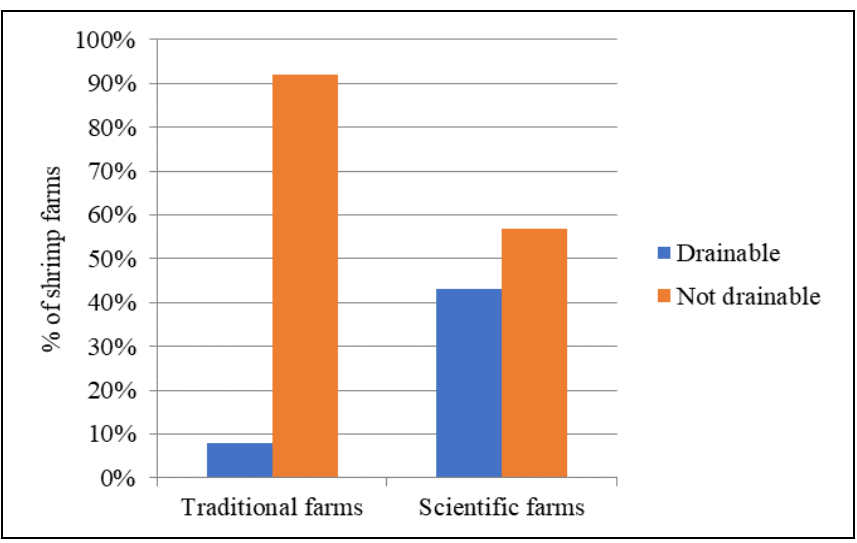

Fig 3: Percent distribution of shrimp farms which are fully drainable/ not drainable.

For successful shrimp farming the shrimp farming site must be free from pollution. The present survey indicated that majority of the traditional farms and a sizeable portion of the scientific farms are located in areas which are either polluted or are under the threat of pollution due to periodic discharge of pollutants from industrial, agricultural, hospital, sewage and/ or other sources (figure 4).

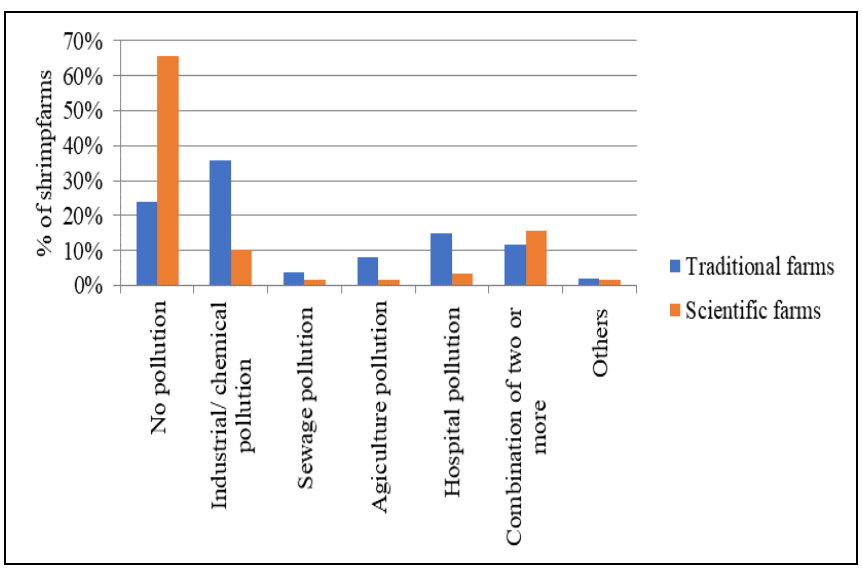

Fig 4: Percent distribution of shrimp farms based on pollution risk.

A few farms (traditional: $11.73 \%$ and scientific: $1.72 \%$ ) were also found to be located in coconut retting areas containing high concentration of hydrogen sulphide which is lethal to shrimp. Hydrogen Sulphide is a by-product of decomposition of coconut husk. This accumulates on the pond bottom and turns the soil black. The $\mathrm{pH}$ regulates the distribution of total sulphides among its forms $\left(\mathrm{H}_{2} \mathrm{~S}, \mathrm{HS}^{-}, \mathrm{S}^{-}{ }^{-}\right)$. Unionized Hydrogen Sulphide is toxic to aquatic organisms ${ }^{12}$. The percentage of hydrogen sulphide decreases as the $\mathrm{pH}$ increases. Therefore, presence of sulphides is considered as an indicator of organic pollution under reducing conditions. Heavy accumulation of hydrogen sulphide results in oxygen depletion leading to mortality of prawns.

Pollution of water acts a major deterrent to improving the productivity of shrimp farms in many areas. Industrial pollution, coconut retting, domestic and city sewage, hospital wastes, pesticides from agriculture fields etc. are all important pollutants of inland water bodies which inhibit the growth of shrimp and thereby reduce the productivity of ponds. Sahadevan ${ }^{6}$ observed that pollution of water body is a very serious issue in some parts of the state of Kerala. According to the author areas which were reputed for prawn production a couple of years back have, of late, become unsuitable for shrimp farming in most parts of the year.
Information collected in the present study on soil $\mathrm{pH}$ of shrimp farms in Kerala are provided in figure 5. In general, the soil is acidic, the pH being 3.3-6.8. In Kerala, 83.95\% of the traditional shrimp farm units and $75.86 \%$ of the scientific farm units were found to be located in acid sulphate/ low $\mathrm{pH}$ areas ( $\mathrm{pH}$ less than 6). Percent distribution of shrimp farms according to soil $\mathrm{pH}$ is provided in figure 6 .

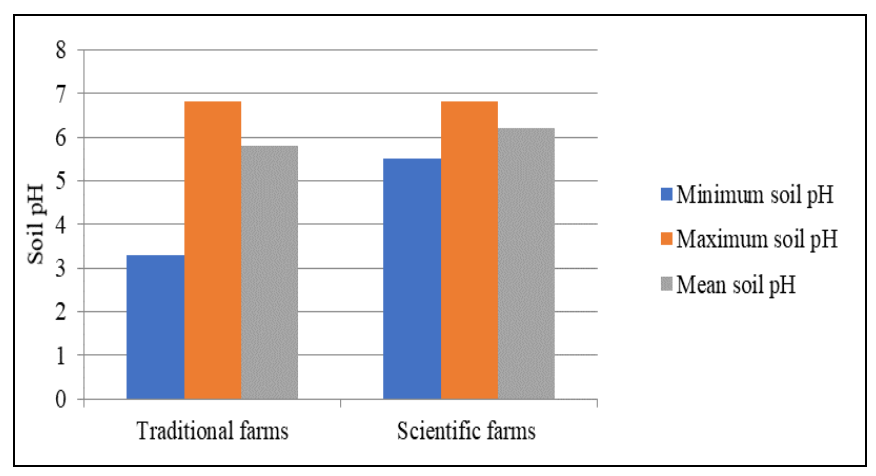

Fig 5: Soil $\mathrm{pH}$ of shrimp farms.

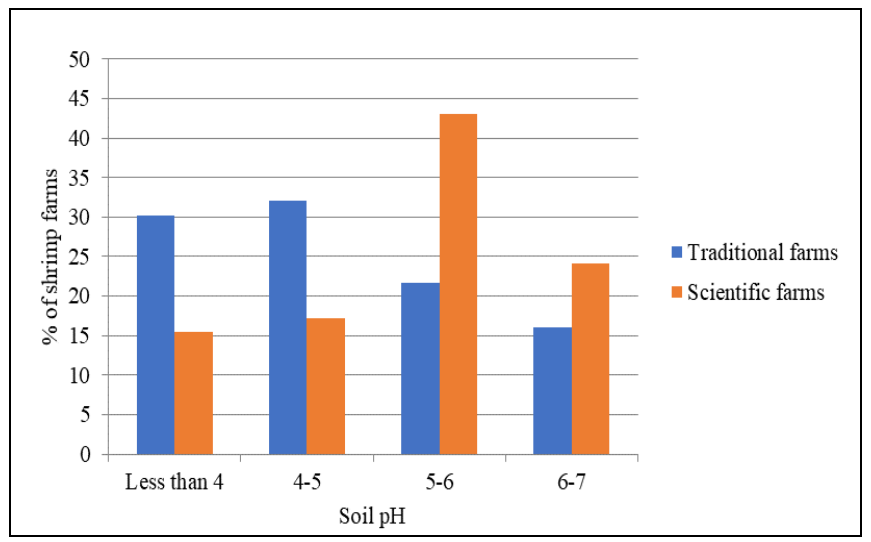

Fig 6: Percent distribution of shrimp farms based on soil $\mathrm{pH}$

Before selecting a site for shrimp farming, the quality of soil should invariably be ascertained for soil $\mathrm{pH}$. Soil with low $\mathrm{pH}$ (below 5) should be avoided. The ideal soil $\mathrm{pH}$ for shrimp farms is $7-8^{9}$. The present study revealed that the soil in the brackish water areas is generally acidic, the $\mathrm{pH}$ being 3.3- 6.8. $83.95 \%$ of the traditional shrimp farm units and $75.86 \%$ of the scientific farm units were found to be located in acid sulphate/ low $\mathrm{pH}$ areas ( $\mathrm{pH}$ less than 6).

Soils with low $\mathrm{pH}$ and acid sulphate areas are not generally considered suitable for prawn farming because it leads to escalation of cost of cultivation and may take a longer period for yielding the desired level of shrimp production. The fact that a sizeable portion of the shrimp farms in Kerala are located in acid sulphate soils or low $\mathrm{pH}$ areas is perhaps one of the important reasons for their inadequate performance. Ponds in acid sulphate soils cannot be drained and dried and may not be amenable to scientific management as drying will lead to lowering of $\mathrm{pH}$ value, as a result of capillary action in the soil ${ }^{[11]}$.

\subsection{Insufficient depth of ponds}

Depth has a direct influence on the production capacity of ponds. Majority of shrimp ponds in Kerala have effective water depths of less than $1.2 \mathrm{~m}$. The details are provided in figure 7 . 


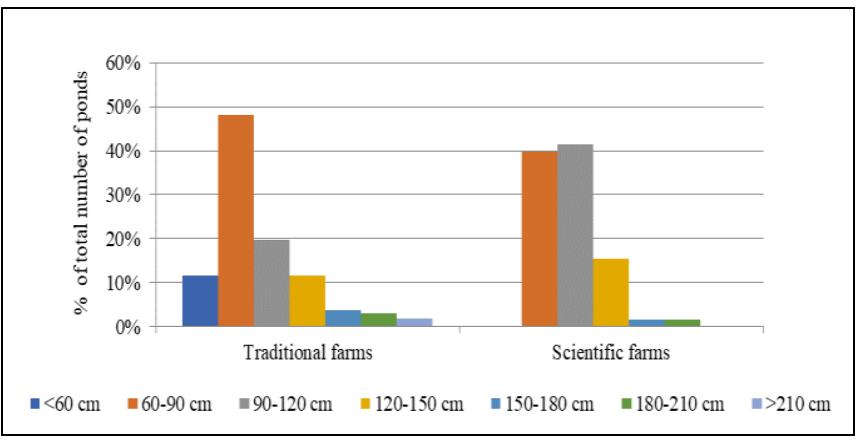

Fig 7: Effective water depth of shrimp ponds (as \% of total number of ponds).

From a biological point of view, an aquaculture pond should have a depth of $2 \mathrm{~m}^{[13,14]}$. Depth of pond has a direct bearing on the physical and chemical qualities of water. On it, but varying with its turbidity, depends the limit of penetration of sunlight which, in turn, determines the temperature and the circulation patterns of the water and the extent of photosynthetic activity ${ }^{[13]}$. In shallow ponds, sun light penetrates up to the bottom, warms up the water and facilitates growth of algal mats at the bottom. Uncontrolled growth of algae may upset the dissolved oxygen balance of the pond and have a deleterious effect on the growth and survival of shrimp. In tropical countries like India, ponds shallower than one metre get heated up in summer period inhibiting survival of the shrimp. Coastal Aquaculture Authority recommended a minimum water depth of 80-100 $\mathrm{cm}$ for farming of $P$. monodon ${ }^{[15]}$ in India. According to Mandal and Dubey ${ }^{[16]}$ for semi-intensive shrimp farming individual ponds with a depth of $1.5-2.0 \mathrm{~m}$ is preferred.

\subsection{Inadequate pond preparation}

Pond preparation is an important measure in improving the productivity of shrimp ponds. As a first step in this direction, draining the pond and drying and tilling the pond bottom assume great importance. In the present study it has been found that the traditional farms and a part of scientific farms do not drain the ponds completely, dry and till the pond bottom as a pre stocking management measure. Only $39.66 \%$ of the total scientific farms $(46 \%$ of the scientific farms which drain and dry the pond) till the pond bottom.

In shrimp farming, as a general rule, pond bottoms should be allowed to dry and crack, primarily to oxidize the organic components left from the previous culture cycle. Drying and tilling the pond bottom also help in better penetration of sunlight and to loosen the soil ${ }^{[17]}$. Mineralization of the organic matter liberates nutrients which will become available for enhancement of primary productivity, mainly phytoplankton, during the following culture cycle. Adequate drying also allows the oxidation of hydrogen sulphide in anaerobic sediment. The presence of hydrogen sulphide not only inhibits primary productivity but may reach levels during the next culture cycle sufficient to inhibit healthy growth of shrimp. Drying the bottom also eliminates fish eggs, crab larvae and potential predators in the humid and wet areas which play a very important role in reducing the final survival rate of shrimp and thereby in decreasing shrimp production. Many authors emphasized the importance of drying of pond bottom $[1,7,17,18,19,20]$. A shrimp pond's carrying capacity will decrease if organic matter is allowed to accumulate on the pond bottom [18, 21]. Desilting is essential in farms where stocking densities are more than 6 post larvae $\mathrm{m}^{2}$ and in those which had experienced diseases during previous crop ${ }^{[22]}$.

\subsection{Inadequate lime application}

$64.20 \%$ of the traditional farms and $100 \%$ of the scientific farms were found to undertake liming as a measure of pond preparation to correct the soil $\mathrm{pH}$ and to improve the total alkalinity. The dose of lime application was found to be less than the dose recommended for farming $[17,20]$.

In general farmers consider that lime is applied to correct the acidity of the pond soil and water ${ }^{7}$. But lime application serves many other functions, too in an aquaculture pond ${ }^{13}$. Lime has been considered as a fertilizer owing to the fact that it supplies calcium, one of the essential nutrients. Lime speeds up the decomposition of organic matter, releasing carbon dioxide from the bottom sediments. It raises bicarbonate content and lack of carbon dioxide will not become a limiting factor for photosynthesis. Liming a pond establishes a strong $\mathrm{pH}$ buffer system. It counteracts the poisonous effect of excess magnesium, potassium and sodium ions. It also fixes harmful acids such as humic acids and inorganic acids. The calcium content of lime displaces certain other fertilizers from organic colloidal system, thus making available greater quantities of such ions as $\mathrm{K}^{+}$and $\mathrm{PO}_{4}{ }^{-}$when they are applied as manure. Treatment of lime is also done to sterilize the soil and control diseases and to neutralize disease conditions ${ }^{17}$. Lime by its toxic and caustic action, kills bacteria as well as parasites in their various life history stages. Thus, inadequate lime application has a direct effect on lowering production and productivity of shrimp farms.

\subsection{Use of poor quality of seed}

$59.79 \%$ of the traditional farms who undertook supplementary stocking (48.15\% of the total traditional farms) and $72.41 \%$ of the scientific farms depended on seeds produced outside the state of Kerala. The seeds were mostly brought from Tamil $\mathrm{Nadu}$, Pondicherry, Andhra Pradesh and Karnataka. The rest of the farms relied on hatcheries functioning inside the State for their seed requirement. $43.59 \%$ of the traditional farms that depended on seeds from hatcheries functioning outside Kerala got seeds through seed supply agents. The rest procured the seeds directly from the seed production centres. Similarly, $38.10 \%$ of the scientific farms that depended on seeds from hatcheries functioning outside the state got the seeds through seed supply agents. The rest procured the seeds directly from the hatcheries.

$54.32 \%$ of the traditional farms and $87.93 \%$ of the scientific farms were found to undertake checking of quality of seeds before stocking. $77.27 \%$ of the former and $94.12 \%$ of the latter were seen to undertake PCR test but others were satisfied with visual observations and/ or stress tests. Further $41.18 \%$ of the traditional farms and $91.67 \%$ of the scientific farms who undertook PCR test were found to get the test done by them. Others depended on the test results provided by the hatchery operators/ other agencies.

Long distance transportation of seeds and failure to ensure its quality undoubtedly result in lower survival rate and yield at harvest.

$51.85 \%$ of the traditional farms and $67.24 \%$ of the scientific farms used seeds which were 20 days or less in age. Information on the age/ size of shrimp seeds used by shrimp farmers are provided in table 1. Majority of the farms used seeds which were 20 days or less in age.

Age of seed has a direct bearing on the productivity. While in the case of white prawn (P. indicus) it may be proper to stock 
PL 5 - PL 10, PL 20 is the ideal stage for black tiger prawn ( $P$. monodon). Use of over aged seed will lead to heavy mortality during transportation and stocking. In view of acute shortage of seed, especially during the peak periods of farming, farmers in Kerala very often have to be content with lesser/ over aged seed leading to lower shrimp production.

Table 1: Age/ size of shrimp seeds stocked.

\begin{tabular}{|c|c|c|c|c|}
\hline Type of farms & < PL 20 & PL 20- 25 & PL 25-30 & > PL 30 \\
\hline Traditional farms & $51.85 \%$ & $34.57 \%$ & $11.73 \%$ & $1.85 \%$ \\
\hline Scientific farms & $67.24 \%$ & $18.97 \%$ & $10.34 \%$ & $3.45 \%$ \\
\hline
\end{tabular}

\subsection{Non acclimatisation of seed}

The importance of acclimatisation of seed before stocking cannot be over emphasised. Perhaps proper acclimatisation is one of the most important management tools for enhancing shrimp production and productivity. The appropriate time for seed stocking is early morning or the late evening. The seed should never be stocked when the water temperature is high. To avoid any abrupt change in water quality and temperature, the seed to be stocked should be kept in a container in the transporting medium to which the pond water should be gradually added. Aeration may also be preferably provided. The container should then be slowly dipped and tilted in the pond so that seed are free to swim out of container in the pond. As a general rule, the adjustment of salinity by about 2ppt per hour is advisable. For best results, seeds are distributed throughout the area when released into the pond.

In the present study, only $27.78 \%$ of the traditional farms (31.03\% of the traditional farms who did supplementary stocking) and $55.17 \%$ of the scientific farms were found to undertake adequate acclimatization of seeds before stocking. It follows that a sizeable portion of farms either do not take adequate care in acclimatization of seeds or do not undertake acclimatization at all. $10.34 \%$ of the scientific farms used 'pond stocking survival bucket' for evaluation of stocking mortality for 48 hours. However, none of the traditional farms were found to adopt such a measure. It is expected that a sizeable number of seed might be dying on the day of stocking or the days that follow immediately. But owing to the small size of seed, the mortality may go unnoticed.

\subsection{Unscientific stocking density}

Information on stocking density adopted by the traditional and scientific shrimp farms is provided in figure 8 and 9 respectively. In the case of the former, the stocking density shown is based on the supplementary stocked seeds and it does not include the naturally stocked ones. The percentage shown refers to the percentage of the farms who undertook supplementary stocking (i.e., $89.51 \%$ of the total traditional farms). In traditional farms the average stocking density in the case of $P$. monodon, $P$. indicus and L. vannamei were 1.25 , 3.50 , and 4.20 post larvae $\mathrm{m}^{-2}$, respectively. In scientific farms the corresponding average stocking densities were 5.71, 7.59 and 32 post larvae $\mathrm{m}^{-2}$.

Stocking density is dependent on the species farmed and the intensity of the culture operation including food availability, water depth and efficiency in water management. In the case of tiger prawn stocking densities in extensive operations may vary from 20, 000 to $80,000 \mathrm{ha}^{-1}$. Stocking densities for semi intensive and intensive systems range from $1,00,000$ to $4,00,000 \mathrm{ha}^{-1}$ with an optimum of $150000-250000 \mathrm{ha}^{-1}$. For white prawns ( $P$. indicus and $L$. vannamei) higher densities may be adopted. L. vannamei is amenable to culture at very high stocking densities of up to $150 \mathrm{~m}^{-2}$ in pond culture, and even as high as $400 \mathrm{~m}^{-2}$ in controlled recirculated tank culture $^{23}$. Although such intensive culture systems require a much higher degree of control over environmental parameters, it enables production of high numbers of shrimp in limited areas, resulting in higher productivity than that currently achievable with $P$. monodon. But $P$. monodon can be aggressive, has high protein requirement, and may be more demanding of high-water quality, making it difficult to culture as intensively as $P$. vannamei.

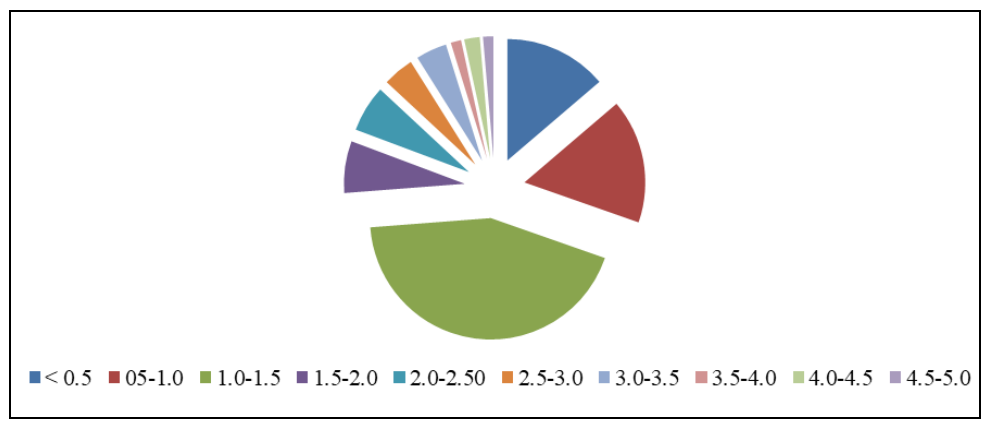

Fig 8: Percentage distribution of traditional shrimp farms based on stocking density (seed $\mathrm{m}^{-2}$ ).

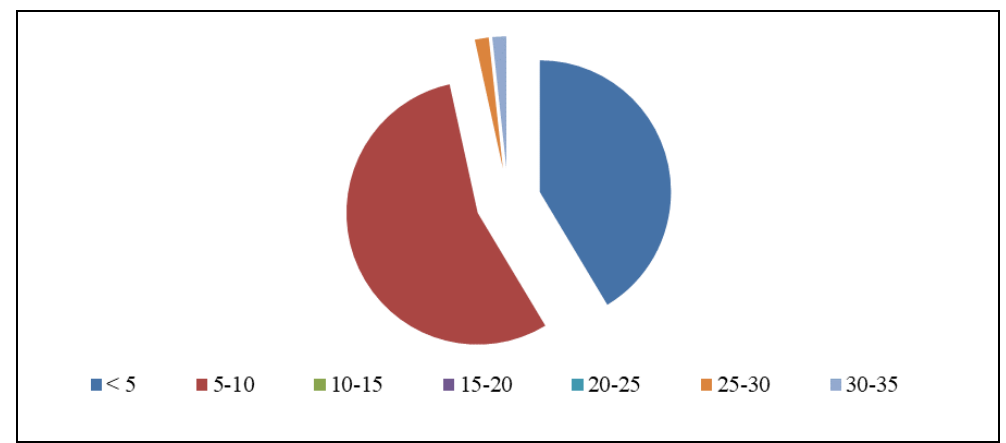

Fig 9: Percentage distribution of scientific shrimp farms based on stocking density (seed $\mathrm{m}^{-2}$ ). 
The scientific shrimp farmers in the state were found to adopt a stocking density anywhere between 5000 seeds $^{-1}$ and 350000 seeds ha ${ }^{-1}$, the average in the case of $P$. monodon, $P$. indicus and L. vannamei being 57,100, 75,900 and 3,20,000 seeds ha $^{-1}$ respectively. In traditional shrimp farms average stocking densities (supplementary stocking) were found to be 12,500, 35,000, and 42,000 seeds $\mathrm{ha}^{-1}$ respectively for $P$. monodon, $P$. indicus and L. vannamei.

As has already been mentioned, stocking density plays an important role in deciding the growth and survival of shrimp and hence the productivity. Other things being constant, the higher the stocking density, the higher will be the shrimp productivity. In Kerala, shrimp farms generally adopt lower stocking densities and hence the productivity achieved is lower.

\subsection{Poor dissolved oxygen management}

Dissolved oxygen is the most important critical factor in any systems of aquaculture. In addition to the direct effect on survival, low dissolved oxygen retards the growth of shrimp and increases the vulnerability to diseases and toxic gases like carbon dioxide, ammonia and hydrogen sulphide.

The volume of oxygen dissolved in water is dependent upon its temperature and the concentration of dissolved salts. Under a given set of conditions, there is a non-linear inverse relation between water temperature and dissolved oxygen, the latter always tending to maintain a normal value towards the saturation point ${ }^{24}$. There is also an inverse relationship between the water salinity and the dissolved oxygen content ${ }^{25}$. It means that concentration of dissolved oxygen decreases with increase in temperature and salinity.

Data on percentage distribution of scientific farms based on average dissolved oxygen content (ppm) during the farming period recorded is presented in table 2 . Only $19.75 \%$ of the traditional farms and $65.52 \%$ of the scientific farms had facilities for measurement of dissolved oxygen at farm level. No traditional farms had aerators. $48.28 \%$ of the scientific farms used aerators for artificial aeration; others used no aerators. Only $1.72 \%$ of the farms operated aerators for more than 12 hours per day. The average duration of working (hours per day) of aerators in scientific farms is provided in figure 10 .

Table 2: Percentage distribution of shrimp farms based on dissolved oxygen content (ppm) during the farming period.

\begin{tabular}{|c|c|c|c|c|c|c|c|c|c|c|}
\hline \multirow{3}{*}{ Stage of crop } & \multicolumn{4}{|c|}{ Traditional farms (\%) } & \multicolumn{4}{c|}{ Scientific farms (\%) } \\
\cline { 2 - 11 } & \multicolumn{3}{|c|}{ Average dissolved oxygen content } & \multicolumn{4}{c|}{ Average dissolved oxygen content } \\
\cline { 2 - 11 } & $\mathbf{5}$ and above & $\mathbf{4 - 5}$ & $\mathbf{3 - 4}$ & $\mathbf{2 - 3}$ & $\mathbf{1 - 2}$ & $\mathbf{5}$ and above & $\mathbf{4 - 5}$ & $\mathbf{3 - 4}$ & $\mathbf{2 - 3}$ & $\mathbf{1 - 2}$ \\
\hline First 30 days & 43.83 & 41.98 & 14.20 & 0 & 0 & 41.38 & 41.38 & 17.24 & 0 & 0 \\
\hline 30-60 days & 41.98 & 38.27 & 19.75 & 0 & 0 & 39.66 & 34.48 & 18.97 & 6.90 & 0 \\
\hline 60-90 days & 38.27 & 35.80 & 22.22 & 3.70 & 0 & 36.21 & 34.48 & 22.41 & 6.90 & 0 \\
\hline 90-120 days & 31.48 & 35.80 & 25.93 & 4.94 & 1.85 & 29.30 & 32.76 & 29.31 & 5.17 & 3.45 \\
\hline
\end{tabular}

For prawn farming the dissolved oxygen content should not go below $3.5 \mathrm{ml}^{-1}{ }^{[26]}$. The optimum level of dissolved oxygen for the farming of $P$. monodon is $5-7 \mathrm{ppm}$ (above $50 \%$ air saturation $)^{15}$. Mandal and Dubey ${ }^{[16]}$ recommended a dissolved oxygen content of more than $5 \mathrm{ppm}$ for $P$. monodon farming. According to Boyd ${ }^{27}$ concentration less than $1 \mathrm{mg} \mathrm{l}^{-1}$ is lethal to shrimp, if exposure lasts for more than a few hours. Growth will be slow if exposure to low dissolved oxygen (1-5 $\left.\mathrm{mg} \mathrm{l}^{-1}\right)$ is continuous. Best condition for good growth occurs when the concentration of dissolved oxygen is between $5 \mathrm{mg} \mathrm{l}^{-1}$ and saturation.

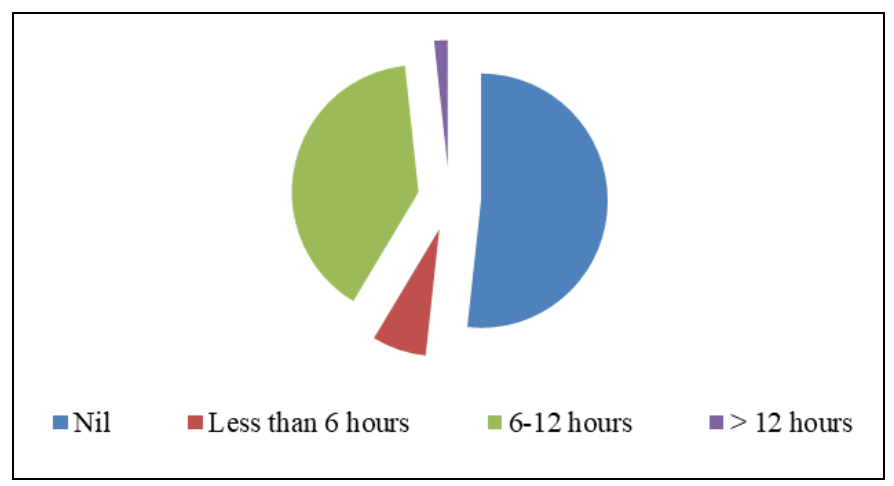

Fig 10: Average number of hours per day during which scientific shrimp farms operate aerators.

The present study showed that the level of dissolved oxygen in a sizeable number of the farms in the state was below the ideal level required for the best growth and survival especially during the third and fourth months of rearing. Concentration of dissolved oxygen in shrimp ponds can fall so low that shrimp in ponds are killed. However, adverse effects of low dissolved oxygen more often are expressed as reduced growth and greater susceptibility to disease. In ponds with chronically low dissolved oxygen concentrations, shrimp will eat less and they will not convert food to flesh as efficiently as in ponds with normal dissolved oxygen concentrations.

\subsection{Poor water exchange}

Information on average quantity of water exchanged per day by various farms in the state is provided in figure 11. Most of the scientific farms were found not to resort to water exchange because they undertook 'zero-water exchange system of farming'. Traditional farms generally were at the mercy of tides for water exchange. Scientific shrimp farms, on the other hand, were found to rely partly on tides and partly on water pumps.

Except in instances of 'zero water exchange systems', water exchange is essential for keeping the quality of the rearing medium. Also, it is required in the case of traditional farms where incoming water is the main source of shrimp seeds. Water exchange ensures replenishment of dissolved oxygen, removal of accumulated organic wastes and correction of turbidity. Proper water exchange ensures healthy growth of the animals and helps avoid occurrence of diseases. In Kerala a vast majority of the shrimp farms are tide-fed which depend up on the prevailing tides for water exchange. Water exchange is at the vagaries of nature and cannot be carried out at the desired time. Inadequate water exchange has a hand in the reported lower shrimp production and productivity in these farms. 


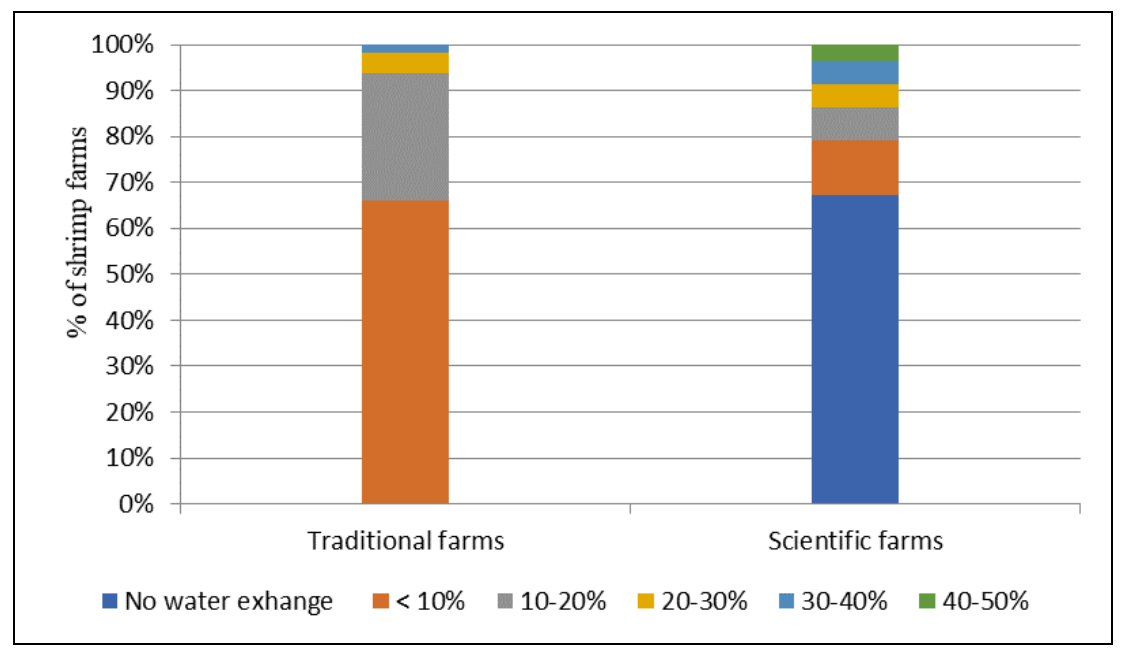

Fig 11: Average quantity of water exchanged in various traditional and scientific shrimp farms

\subsection{Inadequate feeding}

Except a few, most of the traditional farms in the state were found not to use any good quality formulated feed. Many used farm- made feed, the composition of which was determined more by economic consideration rather than nutritional. Ground nut oil cake, dry fish, dry clam meat, rice bran, wheat flour were the principal raw materials in use for making farm made feeds. Vitamin and mineral mix were also added by some farmers. Groundnut oil cake which was abundantly in use in farm made shrimp feeds till a couple of years back was not widely in use during the study period, on account of its higher price. Coconut oil cake had replaced it, at least in some cases. Most of the scientific farms were found to use factory produced feeds and a few farms used farm- made feeds. Information on type of feed used in shrimp farms are provided in table 3. Clam meat was the most important wet feed used by shrimp farmers.

Table 3: Feeds used in shrimp farms

\begin{tabular}{|c|c|c|c|}
\hline \multirow{2}{*}{ Type of farms } & \multicolumn{3}{|c|}{ \% of total number of farms } \\
\cline { 2 - 4 } & No external feeds & Farm made feeds & Factory made feeds \\
\hline Traditional farms & 29.01 & 61.73 & 9.26 \\
\hline Scientific farms & 0 & 8.62 & 91.38 \\
\hline
\end{tabular}

In the present study only $16.67 \%$ of the traditional farms and $87.93 \%$ of the scientific farms were found to ascertain the demand for feed with the help of feed check trays. The rest of the farms fixed the quantity of feed to be given on the basis of wild assumptions or on the basis of previous experience rather than on any scientific assessment of the demand for feed. Traditional farms were not generally in a position to ascertain the quantity of feed to be offered daily, as they were unable to estimate the biomass of shrimp and fin fish available in each pond. In fact, quantity of feed to be given in any aquaculture system is to be ascertained based on the Average Body
Weight $(\mathrm{ABW})$ and the assessed survival rate which are determined by periodic sampling. The exact quantity of feed to be given also varies according to the composition of the feed, the environmental condition including the water temperature and the intensity of culture adopted. However, periodic sampling of prawns was found not to be regularly practised in most cases. Periodic sampling is a pre- requisite for scientific feed management and to know whether the shrimps are growing on expected lines. The quantity of feed used was also found insufficient in many cases.

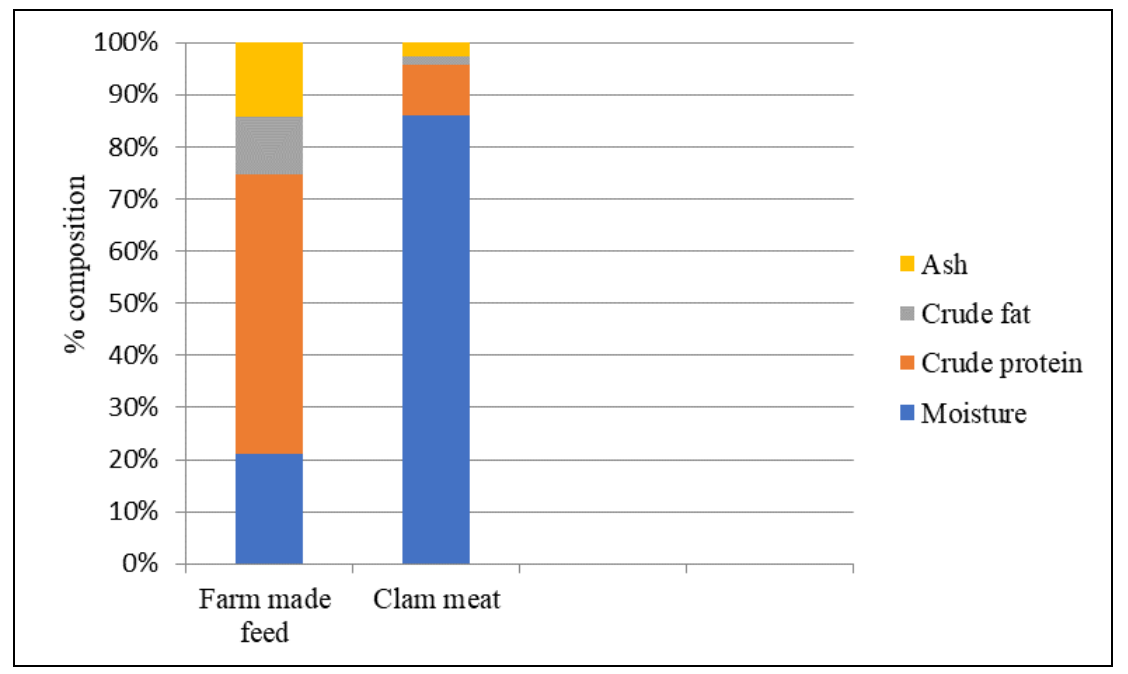

Fig 12: The average nutritional composition of farm made feeds ( $\%$ dry weight) and clam meat used (\% wet weight). 


\subsection{Inadequate management of plankton growth}

Adequate plankton production ('making of water colour') is one of the important aspects to be ensured before seed stocking and during the culture period. It may be ascertained by observation of water colour supported by Secchi disc reading. Most of the shrimp farms $(100 \%$ of the traditional farms and $60.34 \%$ of the scientific farms) were not seen paying adequate attention in ensuring sufficient plankton growth and maintenance of healthy water colour in shrimp ponds, before stocking. In most of the shrimp ponds water colour was not seen developed indicating insufficient phytoplankton growth.

Experienced farmers the world over who had to face repeated mass shrimp mortalities relate shrimp mortality to clear water and lack of 'water colour' in their ponds. Water colour of a shrimp pond is regarded as one of the most essential features that reflects the pond water quality and as an indication of the management skill [7].

Although the true function and benefit of one colour over another is difficult to tell, the intensity and liveliness of the colour, actually indicating the condition of phytoplankton growth, are thought to be more pertinent than the variety of colours per se. The appearance of light and lively water colour indicates the phytoplankton cells to be young and actively growing while the dull and dark colour reflects aged cells with slow growth. Greyish tint in any colour indicates an inactive phytoplankton population or a mixture of decayed uneaten feeds or suspension of bottom mud.

Healthy phytoplankton are known to function as a nutrient sponge soaking up dissolved ammonia, amines, urea, nitrite, nitrate, phosphate, other metabolic wastes from shrimp and toxic substance such as heavy metals and pesticides. Furthermore, phytoplankton being able to produce abundant oxygen under sunlight are efficient aerators. The phytoplankton bloom also reduces light penetration, making the shrimp feel more pleasant in the well shaded pond bottom. Another significant benefit of phytoplankton growth is to prevent the development of 'lab-lab' in the pond bottom.

In spite of the importance, farmers in Kerala in general were not seen paying sufficient attention in developing and managing plankton growth and maintenance of healthy water colour in shrimp ponds. In most of the aged shrimp ponds particularly during the start- up stage of shrimp stocking water colour is not seen developed indicating insufficient phytoplankton growth.

\subsection{Prevalence of diseases}

One of the principal reasons for the low shrimp production in Kerala, as elsewhere in the country, is the oft- recurring disease outbreak. White Spot Disease Syndrome is perhaps the most important cause of massive shrimp mortality. IHHN is also common in some areas which results in retardation of shrimp growth. Absence of shrimp certification and accreditation system enhances the chances of outbreak of diseases in the state. In view of disease outbreak, farmers now take only one crop of shrimp per year, even in areas which are suitable for two crops otherwise. Thus, the fields are grossly underutilised during most part of the year.

The frequency of incidence of diseases in farms during the last five years was taken as an index of assessing the risk associated with disease, in the present study. It may be of quite interest to see that in $95.06 \%$ of the traditional farms and $93.10 \%$ of the scientific farms, there was incidence of diseases. In $9.88 \%$ of the traditional farms and $24.13 \%$ of the scientific farms there was incidence of diseases for four or times during the last five years. Almost all these diseases were reported to be mostly due to viral aetiology.

Frequent incidence of diseases affects the profitability of farming operation and impedes the development of shrimp aquaculture. Some authors observed frequent outbreak of diseases to be one of the most important reasons for the low production and productivity of shrimp farms in this part of the country ${ }^{[1,7,28]}$.

\subsection{Poaching}

One of the most important reasons for the low survival rate and productivity in shrimp farming is poaching. In the present study $40.12 \%$ of the traditional farms and $51.72 \%$ of the scientific farms reported poaching as a major problem.

Poaching is a social issue and can be avoided only by creation of awareness among the local people. In some parts of the state say for example the traditional prawn filtration fields of Ernakulam district (where the majority of the traditional shrimp farms of the state are located), the owner of the field has right over the crop only up to $15^{\text {th }}$ of April (effectively from November to April 15). After $15^{\text {th }}$ April local people can enter the field and catch whatever fish is available in the field viz., it becomes a common property resource. This acts as an impediment for prolonging the crop beyond the date at least in some areas, even today. Thus, the farmers are compelled to harvest their crop before the date mentioned above thereby resulting in lower productivity.

\subsection{Shortage of labourers}

One of the most important issues reported by the shrimp farmers was the shortage of labourers. The issue exists in other agriculture sectors, too. In the present study $43.83 \%$ of the traditional farms and $41.38 \%$ of the scientific farms reported shortage of labourers as a major problem faced by them. Shrimp farms need continuous and close surveillance, for best results. However due to acute shortage of labour force in the state many farms remain 'un manned'. Thus 'corrective measures' cannot be done on time and poaching cannot be avoided, which leads to decrease in shrimp productivity.

\subsection{Discontinuance of paddy farming}

Shrimp farming in Kerala is traditionally practised in pokkali fields (Central Kerala) and in Kaipad areas (North Kerala). Here shrimp farming alternates with paddy farming. The varieties of paddy farmed are flood resistant and salt resistant which require no fertiliser or pesticide application. This type of paddy- shrimp farming benefits both paddy and shrimp in many ways. The decayed organic wastes of paddy increase the fertility of the fields which help improve the shrimp production. However, of late, obviously due to the perceptible drop in the profitability, many farmers discontinued the paddy cultivation which had an obvious negative effect on the production of shrimp.

\subsection{Failure in year- round utilisation of ponds}

Year-round utilisation of ponds is one of the ways to increase productivity and profitability of farming operations. Principally in view of the fear of disease outbreak, shrimp farmers in Kerala take only one crop of shrimp in a year, even in areas which are suitable for two crops. The present study indicated that no farm was utilized for shrimp farming yearround. 93.20\% traditional shrimp farms used the fields for shrimp farming for less than 180 days in a year. Similarly, 
$87.93 \%$ of the scientific farms did shrimp farming for less than 140 days in a year. During the rest of the periods the fields remained idle. It means that the fields were grossly underutilized during most part of the year. Rotation of cropsone crop of shrimp followed by a crop of fin fish- is the way open to circumvent the situation and manage the diseases.

\section{Conclusion}

The present study was undertaken to understand the reasons for the reported low productivity of shrimp farms in the state of Kerala which has traditionally been in the fore front in shrimp production and export, in India. Over- reliance on traditional mode of farming, lack of species diversity, improper site selection, insufficient attention paid on design and construction of ponds, inadequate pond preparation, poor pond management, use of poor quality of seed, nonacclimatisation of seed, sub optimal stocking density, poor dissolved oxygen management, insufficient water exchange, inadequate feeding, inadequate management of plankton growth, recurrence of diseases, poaching, shortage of labourers, discontinuance of paddy farming, failure in yearround utilisation of ponds etc. were found to be the principal reasons for the reported low productivity of shrimp farms in Kerala. By adopting scientific principles in site selection, farm design and construction and by sustainably managing the ponds the state can improve productivity of its shrimp farms and can increase shrimp production many folds.

\section{Acknowledgements}

The authors are thankful to the Principal, MES Ponnani College and the Professor \& Head, Post Graduate Department of Aquaculture and Fisheries Microbiology, MES Ponnani College for providing the facilities for the conduct of the study and for the encouragement. The first author is also thankful to the Director of Fisheries, Department of Fisheries, Government of Kerala for giving permission to him for undertaking the study and for the encouragement.

\section{References}

1. Sahadevan P, Sureshkumar S. Status of Shrimp Farming in Kerala. Paper presented as invited speakers in the International Conference on Aquatic Resources and Blue Economy (AQUABE, 2019) organized by Kerala University of Fisheries and Ocean Studies (KUFOS) held at Kochi, 2019.

2. FAO. The State of World Fisheries and Aquaculture 2020. Sustainability in action. Rome. https://doi.org/10.4060/ca9229en 21 August 2020.

3. GoI. Handbook on Fisheries Statistics-2018. Government of India, Ministry of Fisheries, Animal Husbandry and Dairying, Department of Fisheries, Krishi Bhavan, New Delhi. 2019.

4. ADAK. Kerala Fisheries: Brackishwater Resource Survey-1991 at a Glance. Agency for Development of Aquaculture, Kerala, TC 15/1494, Reeja, Minchin Road, Thiruvananthapuram, Kerala, India, 1991, 29.

5. Sahadevan P. Aquaculture in Kerala: The Ways to Traverse. Paper presented in the Global Agro Meet- 2014 held at Adlex International Convention Centre, Kochi, 67, November Kochi, India, 2014

6. https://mpeda.gov.in/MPEDA/cms.php?id=YXJ1YS11bm Rlci1jdWx0dXJl\#

7. Sahadevan P. Reasons for the low productivity of shrimp farms in Kerala. Fishing Chimes. 2012; 31(12):27-30.
8. Wickins JF. Prawn biology and culture. Oceanogr. Mar. Biol. Annu. Rev. 1976; (14):435-507.

9. Holthuis LB. Shrimps and prawns of the world; an annotated catalogue of species of interest to fisheries. Food and Agriculture Organization of the United Nations, Rome, (FAO Species Catalogue;). 1980; 1:271 .

10. Unnithan KA. Guide to Prawn farming in Kerala. CMFRI Special Publication, 1985; 21:92.

11. Sahadevan P. Development of Aquaculture in Kerala: Strategies. Fishing Chimes. 2013; 32(10):62-67.

12. Krishnani KK, Kathiravan V, Natarajan M, Kailasam M, Pillai SM. Diversity of sulphur- oxidizing bacteria in green water system of coastal aquaculture. Appl. Biochem. Biotechnol. 2010; 162:1225-1237.

13. Jhingran VG. Fish and Fisheries of India. Hindustan Publication house, New Delhi, 1991, 727.

14. Sinha VRP, Srivastava HC. Aquaculture Productivity. New Delhi: Oxford and IBH Publishing Co. Sinha, 1983.

15. CAA. Coastal Aquaculture Authority - Compendium of Act, Rules, Guidelines and Notifications Coastal Aquaculture Authority, Chennai. 2006, 132.

16. Mandal B, Dubey SK. Present Status and Prospects of Black Tiger Shrimp Farming: A Case Study in Maritime State of West Bengal, India. In: Gupta VK, Verma AK and Singh GD (Eds.). Perspectives in Animal Ecology and Reproduction Volume 10. Daya Publishing House, New Delhi - 110 002. 2015.

17. Apud FD. Prawn Grow-out Practices in The Philippines. In: Biology and Culture of Penaeus monodon. Brackish water Aquaculture Information System, Aquaculture Department, Southeast Asian Fisheries Development Centre Tigbauan, Iloilo, Philippines, 1988, 89-118.

18. Wang JK, Fast AW. Shrimp Pond Engineering Considerations. In: Fast AW and Lester LJ. (Eds.) Marine Shrimp Culture Principles and Practices. Developments in Aquaculture and Fisheries Science. Elsevier B.V. 1992, 415-429.

19. Galib SM, Mohsin ABM, Chaki N, Fahad MFH, Haque SMM. An overview of the traditional rice -prawn-fish farming in Kalia of Narail district, Bangladesh. Journal of Fisheries, 2013; 1(1):1-6.

20. CIBA. Training Manual on Aquatic Animal Health Management in Brackish water Aquaculture. Central Institute of Brackishwater Aquaculture, 75, Santhome High Road, R.A. Puram, Chennai 600028. 2015, 140.

21. Lin CK. Prawn culture in Taiwan- What went wrong? World Aquaculture. 1989; 20:19-20.

22. Nagesh TS, Abraham TJ, Ghosh AR. Threats Associated with Non-infectious Diseases in Modified Extensive Shrimp Farming Systems of West Bengal, India. Asian Fisheries Science. 2009; 22:1015-1029.

23. Briggs M, Funge-Smith S, Subasinghe R, Phillips M. Introductions and movement of Penaeus vannamei and Penaeus stylirostris in Asia and the Pacific. Food and Agriculture Organization of the United Nations, Regional Office for Asia and the Pacific, Bangkok, 2004, 92.

24. Welch PS. Limnology II edition Mc. Graw Hill Book Co., New York, 1952.

25. Boyd CE. Water quality management and aeration in shrimp farming. Fisheries and Allied Aquaculture Departmental Series, vol. 2. Alabama Agricultural Experiment Station, Auburn University, Alabama, 1989.

26. Suseelan $\mathrm{C}$. The environmental requirements for culture of marine prawns. Summer Institute in Breeding and 
rearing of marine prawns. CMFRI sp. pub.3, 1999, 103109.

27. Boyd CE. Water quality management for pond fish culture. Elsevier, Armsterdam, Netherlands, 1982.

28. Sahadevan P, Sureshkumar S. Shrimp Aquaculture in India - the Way Forward. Paper presented in the $3^{\text {rd }}$ International Symposium on Marine Ecosystems Challenges and Opportunities (MECOS3) organized by the Marine Biological Association of India (MBAI) to be held at Kochi, 2020. 